\title{
ANALIZA TRAJANJA STUDIRANJA NA PREDDIPLOMSKIM STUDIJIMA ŠUMARSKOG FAKULTETA SVEUČILIŠTA U ZAGREBU
}

\section{ANALYSING THE DURATION OF STUDYNG ON UNDERGRADUATE STUDIES ET THE FACULTY OF FORESTRY, UNIVERSITY OF ZAGREB}

\author{
Anamarija JAZBEC ${ }^{1}$, Mislav VEDRIŠ², Ksenija ŠEGOTIĆ
}

\begin{abstract}
SAŽETAK
Iako se šumarstvo smatra tradicionalnom strukom i područjem znanosti, njegova važnost i značenje u današnjim prilikama povećane svijesti o klimatskim promjena i dobrobiti održivog razvoja prirodnih ekosustava svakim danom sve više raste. Suvremeni i ažurirani studijski programi neophodni su uvjet za primjereno obrazovanje stručnjaka za gospodarenje šumskim ekosustavima i proizvodima.

Bolji uvid u studentsku socioekonomsku pozadinu i motivaciju za studij mogu poslužiti za unapređenje studijskih programa, kao i pomoć studentima u postizanju boljih rezultata. Provedeno je istraživanje radi usporedbe trajanja preddiplomskog studija i postignute prosječne ocjene s analizom čimbenika koji bi mogli na to utjecati. Proveden je upitnik među studentima ( $\mathrm{N}=185)$ diplomskih studija Šumarskog fakulteta Sveučilišta u Zagrebu akademske godine 2016/2017. Analizom varijance testirane su razlike između prosječnih ocjena studija i trajanja studija. Za procjenu utjecaja čimbenika na trajanje studija provedena je višestruka linearna regresija.

Približno trećina studenata dolazi iz Zagreba. Više od dvije trećine studenata na šumarskom odsjeku je završilo gimnaziju, dok su na drvnotehnološkom odsjeku dvije trećine studenata završile srednje strukovne škole. Prosječne ocjene i trajanje studija ne razlikuju se statistički značajno po studijskim programima ni po spolu. Prosječna ocjena studija i trajanje studija statistički su značajno negativno korelirani za sva tri studijska programa. Statistički značajni prediktor trajanja studija za sva tri studijska programa je prosječna ocjena studija. Za studij Šumarstvo dodatni prediktori za kraće studiranje su stipendija i osobna motivacija, dok su za studij drvne tehnologije spol (M), stipendija i završena srednja škola (gimnazija).
\end{abstract}

KLJUČNE RIJEČI: uspjeh studenata, prosječna ocjena, trajanje studija, regresijska analiza, studijski program

\section{UVOD}

\section{INTRODUCTION}

Šumarstvo kao struka i znanost s dugogodišnjom tradicijom u Hrvatskoj nalazi se pred izazovima usklađivanja s današnjim ekološkim, društvenim i gospodarskim okolnostima, gdje prirodni resursi dobivaju novo značenje (Anić 2019). Osim toga, prirodne promjene od kojih su najistaknutije one klimatske, nameću potrebu prilagodbe gospodarenja šumama.

\footnotetext{
${ }^{1}$ Prof. dr. sc. Anamarija Jazbec, Zavod za izmjeru i uređivanje šuma, Šumarski fakultet Sveučilišta u Zagrebu, Svetošimunska 25, Zagreb, e-mail: jazbec@sumfak.hr ${ }^{2}$ Doc. dr. sc. Mislav Vedriš, Zavod za izmjeru i uređivanje šuma, Šumarski fakultet Sveučilišta u Zagrebu, Svetošimunska 25, Zagreb, e-mail: mvedris@sumfak.hr ${ }^{3}$ Prof. dr. sc. Ksenija Šegotić, Zavod za procesne tehnike, Šumarski fakultet Sveučilišta u Zagrebu, Svetošimunska 25, Zagreb, e-mail: segotic@sumfak.hr
} 
Bitna sastavnica i temelj šumarstva svakako je šumarska naobrazba koja se u Hrvatskoj provodi na visokoškolskoj razini od 1898. godine (Božić 2018). U sklopu prilagodbe na promjene potaknute Bolonjskom deklaracijom (1999.), od akademske godine 2005./06. studiji na Šumarskom fakultetu Sveučilišta u Zagrebu izvode se na tri razine preddiplomski, diplomski i poslijediplomski, čime je dotadašnji četverogodišnji dodiplomski sveučilišni studij preustrojen u preddiplomski (3 god.) i diplomski (2 god.) studij. Na Šumarskom odsjeku provode se dva preddiplomska sveučilišna studija (Šumarstvo - ŠO i Urbano šumarstvo, zaštita prirode i okoliša - UŠ) i dva diplomska ( ̌̌umarstvo: smjer Uzgajanje i uređivanje šuma s lovnim gospodarenjem - DUULG i smjer Tehnike, tehnologije i menadžment u Šumarstvu - DTTM i Urbano šumarstvo, zaštita prirode i okoliša - DUŠ). Na drvnotehnološkom odsjeku provodi se jedan preddiplomski (Drvna tehnologija - DT) i dva diplomska sveučilišna studija (Drvnotehnološki procesi - DTP i Oblikovanje proizvoda od drva - DTOB).

U današnjim okolnostima od obrazovnog sustava se sve više očekuje prilagodba društvenim prilikama, te se nameće potreba analize i planiranja ishoda nastavnog procesa, kao i čimbenika koji potpomažu ili otežavaju sam tijek studiranja. U tom kontekstu vrijedan je prilog iskazati uspješnost studiranja mjerljivim pokazateljima kao što su prosječna ocjena i trajanje studija. Takva se analiza može provesti iz službenih statističkih podataka pojedinih obrazovnih ustanova (usp. Tešija i dr. 2013, Zrakić i Juračak 2012). Uvođenjem Informacijskog sustava visokih učilišta RH (ISVU) (Borčić 2003) na Šumarskom fakultetu od 2007. godine digitaliziran je sustav ocjenjivanja studenata (prolaznosti), što također omogućuje brojne analize uspješnosti studiranja. Međutim, utjecaj pojedinih čimbenika na prolaznost i trajanje studija nije moguće pratiti bez dodatnog anketiranja samih studenata.
Kako bi se pokušalo utvrditi čimbenike koji utječu na ishod i trajanje studiranja na preddiplomskim studijima Šumarskoga fakulteta, što je i glavni cilj ovog istraživanja, osmišljen je anketni upitnik za studente svih diplomskih studija oba odsjeka Šumarskog fakulteta koji su završili jedan od preddiplomskih studija na Šumarskom fakultetu: Šumarstvo; Urbano šumarstvo, zaštita prirode i okoliša; Drvna tehnologija.

\section{MATERIJALI I METODE MATERIAL AND METHODS}

Tijekom akademske godine 2016./2017., uz odobrenje Dekana i predmetnog nastavnika, anketirani su studenti svih diplomskih studija na oba odsjeka. Od ukupno 220 upisanih studenata na sve diplomske studije anketirano ih je 185 (84,09\%). Distribucija broja upisanih i broja anketiranih studenata diplomskih studija prikazana je u Tablici 1. Upitnik je sadržavao tri grupe pitanja. Prva grupa pitanja bila je vezana za spol (m/ž), godinu rođenja, županiju prebivališta, studij, smjer i godina diplomskog studija na kojem se nalaze prilikom ispunjavanja upitnika. Druga grupa pitanja vezana je za preddiplomski studij i uvjete studiranja: godina upisa, završena srednja škola (strukovna/gimnazija), koji je na prioritetnoj listi bio Šumarski fakultet prilikom upisa, upisani studij i smjer, godina završetka preddiplomskog studija, primanje stipendije tijekom preddiplomskog studija (da/ne), zaposlenost tijekom preddiplomskog studija (da/ ne), prosječna ocjena preddiplomskog studija, te glavna motivacija da se završi Šumarski fakultet (vlastiti interes / interes obitelji). Prosječna ocjena (GPA) računa se kao prosjek ocjena svih položenih predmeta u rasponu od 2 do 5 , pri čemu 5 predstavlja najbolju ocjenu. Treća grupa pitanja koja nije uvrštena u ovu analizu bila je vezana za rezultate državne mature. Treba napomenuti da su svi podaci dobiveni od samih studenata. Primijenjenim načinom priku-

Tablica 1. Tablica frekvencija upisanih i anketiranih studenata po studijima i godinama studija Table 1. Frequency table of enrolled and surveyed students by study programmes

\begin{tabular}{|c|c|c|c|c|c|c|c|}
\hline \multirow{3}{*}{$\begin{array}{l}\text { Godina studija } \\
\text { Year of study }\end{array}$} & \multicolumn{5}{|c|}{ Diplomski studijski program / Master Study programme } & \multirow{3}{*}{$\begin{array}{l}\text { Ukupno } \\
\text { Total }\end{array}$} & \multirow{3}{*}{$\begin{array}{l}\text { anketirani/upisani (\%) } \\
\text { surveyed/enrolled (\%) }\end{array}$} \\
\hline & DUULG & DTTM & DUŠ & DTP & DTOB & & \\
\hline & \multicolumn{5}{|c|}{$\begin{array}{l}\text { Broj anketiranih/broj upisanih } \\
\text { Surveyed/enrolled }\end{array}$} & & \\
\hline $\begin{array}{l}\text { 1.godina } \\
\text { 1st year }\end{array}$ & $27 / 31$ & $15 / 16$ & $32 / 33$ & $12 / 16$ & $7 / 7$ & $93 / 103$ & $90,29 \%$ \\
\hline $\begin{array}{l}\text { 2. godina } \\
\text { 2nd year }\end{array}$ & $30 / 36$ & $20 / 21$ & $22 / 34$ & $12 / 17$ & $8 / 9$ & $92 / 117$ & $78,63 \%$ \\
\hline $\begin{array}{c}\text { Ukupno } \\
\text { Total }\end{array}$ & $57 / 67$ & $35 / 37$ & $54 / 67$ & $24 / 33$ & $15 / 16$ & $185 / 220$ & $84,09 \%$ \\
\hline
\end{tabular}

Nazivi diplomskih studija: DUULG - Šumarstvo: smjer Uzgajanje i uređivanje šuma s lovnim gospodarenjem; DTTM - Šumarstvo: smjer Tehnike, tehnologije i menadžment u Šumarstvu; DUŠ - Urbano šumarstvo, zaštita prirode i okoliša ; DTP - Drvnotehnološki procesi; DTOB - Oblikovanje proizvoda od drva

Master study programmes: DUULG - Forestry: Silviculture and Management planning with Wildlife management; DTTM - Forestry: Techniques, Technologies and Forestry Management; DUŠ - Urban Forestry, Nature conservation and Environmental protection; DTP - Wood Technology Processes; DTOB - Wood Product Design 
pljanja podataka nisu bili obuhvaćeni studenti preddiplomskih studija koji nisu upisali diplomski studij, kao ni oni koji nisu završili preddiplomski studij, što predstavlja određeno ograničenje u interpretaciji rezultata. Analizom prosječnih ocjena studenata preddiplomskih studija studenata koji su završili preddiplomski studij akademske godine 2015./2016. iz ISVU-a vidljivo je da je odnos prosječnih ocjena po studijskim programima približno jednak onim dobivenim putem upitnika.

\section{STATISTIČKA ANALIZA STATISTICAL ANALYSIS}

Za sve analizirane varijable napravljena je deskriptivna statistika. Za kategorijske varijable to su frekvencije i relativne frekvencije, a za numeričke: minimum, medijan, maksimum, aritmetička sredina i standardna devijacija. Razlike u trajanju, kao i prosječnoj ocjeni preddiplomskog studija s obzirom na smjer studija i spol studenta testirane su dvofaktorskom analizom varijance s interakcijom studija i spola. Korelacijskom analizom testirana je povezanost prosječne ocjene i trajanja preddiplomskog studija po smjerovima. Utjecaj analiziranih varijabli (spol, stipendija, prosječna ocjena, završena srednja škola, prioritet fakulteta pri upisu, zaposlenost tijekom studija i motivacija upisa) na trajanje studija analizirana je višestrukom regresijskom analizom posebno po studijima. Razlika u trajanju preddiplomskog studija i prosječnim ocjenama preddiplomskog studija po upisanim smjerovima diplomskih studija analizirana je jednofaktorskom analizom varijance. S obzirom da trajanje studija i prosječna ocjena studija nisu normalno distribuirane za potrebe statističkih analiza (ANOVA i višestruka regresija) su logaritmirane. Grafički prikazi su napravljeni s originalnim podatcima.

Za sve statističke analize razina značajnosti (pogreška tipa I) od 5\% smatrana je statistički značajnom ako nije drukčije

Tablica 2. Frekvencije i relativne frekvencije za kategorijske varijable: spol, srednja škola, motivacija, zaposlenost i stipendija prema studijskim programima

Table 2. Frequency table for categorical variables (sex, type of high school, motivation, employment and grant) by study programmes

\begin{tabular}{|c|c|c|c|c|c|}
\hline & & \multicolumn{3}{|c|}{$\begin{array}{l}\text { Studijski programi } \\
\text { Study programme }\end{array}$} & \multirow[b]{2}{*}{$\begin{array}{c}\text { Ukupno } \\
\text { Total }\end{array}$} \\
\hline & & Šo & UŠ & DT & \\
\hline \multirow{3}{*}{$\begin{array}{l}\text { Spol } \\
\text { Sex }\end{array}$} & $\begin{array}{c}\text { Studentice } \\
F\end{array}$ & $\begin{array}{c}18 \\
19,78 \%\end{array}$ & $\begin{array}{c}35 \\
64,81 \%\end{array}$ & $\begin{array}{c}9 \\
23,08 \%\end{array}$ & $\begin{array}{c}62 \\
33,70 \%\end{array}$ \\
\hline & $\begin{array}{l}\text { Studenti } \\
M\end{array}$ & $\begin{array}{c}73 \\
80,22 \%\end{array}$ & $\begin{array}{c}19 \\
35,19 \%\end{array}$ & $\begin{array}{c}30 \\
76,92 \%\end{array}$ & $\begin{array}{c}122 \\
66,30 \%\end{array}$ \\
\hline & $\begin{array}{l}\text { Ukupno } \\
\text { Total }\end{array}$ & $\begin{array}{c}91 \\
(49,46 \%)\end{array}$ & $\begin{array}{c}54 \\
(29,35 \%)\end{array}$ & $\begin{array}{c}39 \\
(21,20 \%)\end{array}$ & $\begin{array}{c}184 \\
(100 \%)\end{array}$ \\
\hline \multirow{3}{*}{$\begin{array}{c}\text { Vrsta srednje škole } \\
\text { High school type }\end{array}$} & $\begin{array}{l}\text { Gimnazija } \\
\text { Gymnasium }\end{array}$ & $\begin{array}{c}61 \\
67,03 \%\end{array}$ & $\begin{array}{c}45 \\
83,33 \%\end{array}$ & $\begin{array}{c}11 \\
28,21 \%\end{array}$ & $\begin{array}{c}117 \\
63,59 \%\end{array}$ \\
\hline & $\begin{array}{l}\text { Strukovna } \\
\text { Vocational }\end{array}$ & $\begin{array}{c}30 \\
32,97 \%\end{array}$ & $\begin{array}{c}9 \\
16,67 \%\end{array}$ & $\begin{array}{c}28 \\
71,79 \%\end{array}$ & $\begin{array}{c}67 \\
36,41 \%\end{array}$ \\
\hline & $\begin{array}{l}\text { Ukupno } \\
\text { Total }\end{array}$ & $\begin{array}{c}91 \\
(49,73 \%)\end{array}$ & $\begin{array}{c}54 \\
(29,19 \%)\end{array}$ & $\begin{array}{c}39 \\
(21,08 \%)\end{array}$ & $\begin{array}{c}184 \\
(100 \%)\end{array}$ \\
\hline \multirow{3}{*}{$\begin{array}{l}\text { Motivacija } \\
\text { Motivation }\end{array}$} & $\begin{array}{c}\text { Osobni } \\
\text { Personal }\end{array}$ & $\begin{array}{c}83 \\
91,21 \%\end{array}$ & $\begin{array}{c}48 \\
88,89 \%\end{array}$ & $\begin{array}{c}35 \\
92,11 \%\end{array}$ & $\begin{array}{c}166 \\
90,71 \%\end{array}$ \\
\hline & $\begin{array}{l}\text { Interes obitelji } \\
\text { Family }\end{array}$ & $\begin{array}{c}8 \\
8,79 \%\end{array}$ & $\begin{array}{c}6 \\
11,11 \%\end{array}$ & $\begin{array}{c}3 \\
7,89 \%\end{array}$ & $\begin{array}{c}17 \\
9,29 \%\end{array}$ \\
\hline & $\begin{array}{c}\text { Ukupno } \\
\text { Total }\end{array}$ & $\begin{array}{c}91 \\
(49,73 \%)\end{array}$ & $\begin{array}{c}54 \\
(29,51 \%)\end{array}$ & $\begin{array}{c}38 \\
(20,77 \%)\end{array}$ & $\begin{array}{c}183 \\
(100 \%)\end{array}$ \\
\hline \multirow{3}{*}{$\begin{array}{l}\text { Zaposlenost } \\
\text { Employment }\end{array}$} & $\begin{array}{l}\text { Da } \\
\text { Yes }\end{array}$ & $\begin{array}{c}48 \\
52,17 \%\end{array}$ & $\begin{array}{c}30 \\
55,56 \%\end{array}$ & $\begin{array}{c}26 \\
66,67 \%\end{array}$ & $\begin{array}{c}104 \\
56,22 \%\end{array}$ \\
\hline & $\begin{array}{l}\mathrm{Ne} \\
\mathrm{No}\end{array}$ & $\begin{array}{c}44 \\
47,83 \%\end{array}$ & $\begin{array}{c}24 \\
44,44 \%\end{array}$ & $\begin{array}{c}13 \\
33,33 \%\end{array}$ & $\begin{array}{c}81 \\
43,78 \%\end{array}$ \\
\hline & $\begin{array}{l}\text { Ukupno } \\
\text { Total }\end{array}$ & $\begin{array}{c}92 \\
(49,73 \%)\end{array}$ & $\begin{array}{c}54 \\
(29,19 \%)\end{array}$ & $\begin{array}{c}39 \\
(21,08 \%)\end{array}$ & $\begin{array}{c}185 \\
(100 \%)\end{array}$ \\
\hline \multirow{3}{*}{$\begin{array}{l}\text { Stipendija } \\
\text { Grant }\end{array}$} & $\begin{array}{l}\text { Da } \\
\text { Yes }\end{array}$ & $\begin{array}{c}21 \\
22,83 \%\end{array}$ & $\begin{array}{c}12 \\
22,22 \%\end{array}$ & $\begin{array}{c}12 \\
30,77 \%\end{array}$ & $\begin{array}{c}45 \\
24,32 \%\end{array}$ \\
\hline & $\begin{array}{l}\mathrm{Ne} \\
\mathrm{No}\end{array}$ & $\begin{array}{c}71 \\
77,17 \%\end{array}$ & $\begin{array}{c}42 \\
77,78 \%\end{array}$ & $\begin{array}{c}27 \\
69,23 \%\end{array}$ & $\begin{array}{c}140 \\
75,68 \%\end{array}$ \\
\hline & $\begin{array}{l}\text { Ukupno } \\
\text { Total }\end{array}$ & $\begin{array}{c}92 \\
(49,73 \%)\end{array}$ & $\begin{array}{c}54 \\
(29,19 \%)\end{array}$ & $\begin{array}{c}39 \\
(21,08 \%)\end{array}$ & $\begin{array}{c}185 \\
(100 \%)\end{array}$ \\
\hline
\end{tabular}

Nazivi preddiplomskih studija: Šo -Šumarstvo; UŠ -Urbano šumarstvo, zaštita prirode i okoliša; DT - Drvna tehnologija Undergraduate study programmes: ŠO -Forestry; UŠ - Urban Forestry, Nature consenvation and Environmental protection; DT - Wood Technology 


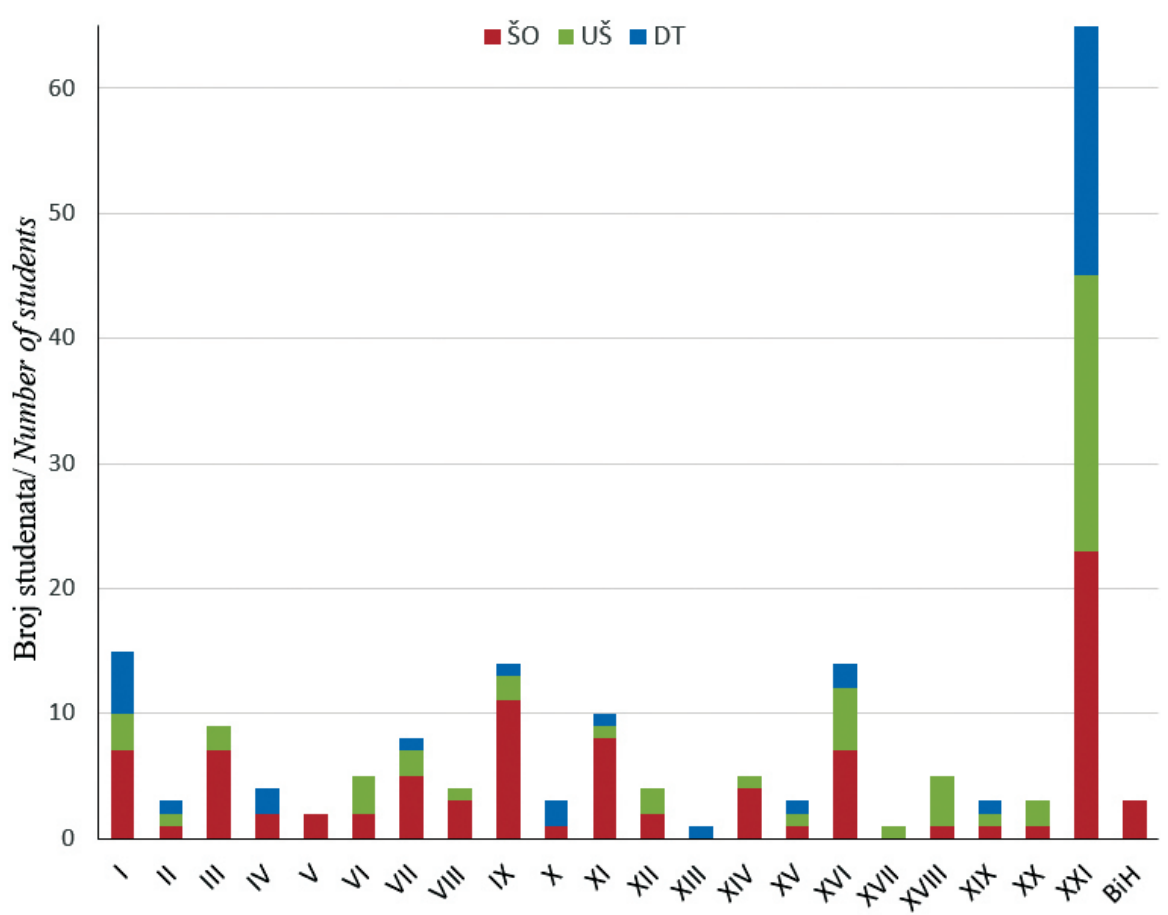

Županija / County

\begin{tabular}{|c|c|}
\hline \multicolumn{2}{|c|}{ Prebivalište (županije) / Residence (counties } \\
\hline I & ZAGREBAČKA \\
\hline II & KRAPINSKO-ZAGORSKA \\
\hline III & SISAČKO-MOSLAVAČKA \\
\hline IV & KARLOVAČKA \\
\hline $\mathrm{v}$ & VARAŽDINSKA \\
\hline VI & KOPRIVNIČKO-KRIŽEVAČKA \\
\hline VII & BJELOVARSKO-BILOGORSKA \\
\hline VIIII & PRIMORSKO-GORANSKA \\
\hline IX & LIČKO-SENJSKA \\
\hline $\mathrm{x}$ & VIROVITIČKO-PODRAVSKA \\
\hline $\mathrm{XI}$ & POŽEŠKO-SLAVONSKA \\
\hline XII & BRODSKO-POSAVSKA \\
\hline XIII & ZADARSKA \\
\hline XIV & OSJEČKO-BARANJSKA \\
\hline XV & ŠIBENSKO-KNINSKA \\
\hline XVI & VUKOVARSKO-SRIJEMSKA \\
\hline XVII & SPLITSKO-DALMATINSKA \\
\hline XVIII & ISTARSKA \\
\hline $\mathrm{XIX}$ & DUBROVAČKO-NERETVANSKA \\
\hline $\mathrm{xx}$ & MEĐIMURSKA \\
\hline $\mathrm{XXI}$ & GRAD ZAGREB \\
\hline $\mathrm{BiH}$ & Bosna i Hercegovina \\
\hline
\end{tabular}

Slika 1. Broj anketiranih studenata po prebivalištu (županije) i studijskim programima Figure 1. Number of students by place of residence (counties) and study programmes

naznačeno. Statističke analize napravljene su u statističkom paketu SAS Software 9.4 (SAS Institute Inc), a grafički prikazi u SAS9.4 (korelacijska analiza) i Excelu (stupčasti graf), te ANOVA u statističkom paketu STATISTICA (TIBCO Software Inc. 2018).

\section{REZULTATI I RASPRAVA RESULTS AND DISCUSSION}

Iz Tablice 2 vidljivo da je broj studenata koji su završili preddiplomski studij i upisali diplomski studij bio na studijima Šumarstvo i Drvna tehnologija skoro 4 puta veći od broja studentica, dok je na studiju Urbano šumarstvo broj studenata za $45,7 \%$ manji od broja studentica.

Gimnaziju je završilo 63,6\% studenata, dok je strukovne škole završilo 36,4\% studenata. Gimnaziju je na studiju Šumarstvo završilo dvostruko više studenata nego strukovne škole, dok je na studiju Urbano šumarstvo, zaštita prirode i okoliša4 puta više, a na studiju Drvne tehnologije je situacija donekle obrnuta pa je 2,5 puta veći broj studenata koji su završili strukovne škole od gimnazije. Što se tiče motivacije da se završi Šumarski fakultet samo njih $9 \%$ je navelo da glavni motiv za završetak fakulteta nije bio vlastiti interes, nego interes obitelji. Najveći udio takvih studenata je na studiju Urbanog šumarstva, zaštita prirode i okoliša $(11,11 \%)$. Preko polovice studenata (56\%) je radilo tijekom preddiplomskog studija i to najveći udio na drvno tehno- loškom odsjeku (66,67\%). 24\% studenata je tijekom preddiplomskog studija primalo stipendiju. Na žalost, podatci o veličini stipendije po godinama studiranja nisu bili upotrebljivi za analizu.

Analiza studenata prema županijama pokazuje da više od trećine (35,33\%) studenata dolazi iz Grada Zagreba, a ostale županije su zastupljene s manje od $10 \%$, pri čemu je Zagrebačka županija zastupljena s $8,15 \%$ studenata, slijede Ličkosenjska i Vukovarsko-srijemska s 7,61\%, te Požeško-slavonska s 5,43\%. Sve ostale županije su zastupljene s manje od $5 \%$ (Slika 1).

Od svih anketiranih studenata njih $60,11 \%$ se izjasnilo da im je Šumarski fakultet bio prvi izbor pri upisu na fakultet, za njih $20,79 \%$ bio je drugi, za 9,55\% treći, a preostalih 9,55\% se izjasnilo da im je Šumarski fakultet bio od četvrtog do desetog mjesta (Tablica 3).

Prosječna dob svih anketiranih studenata je bila 24,93 $\pm 1,55$ god. Iz tablice 4 . Vidljivo je da polovica studenata za 4 godine završi preddiplomski studij. Iz tablice 4 i slike 4 . vidljivo je da studenti koji završe preddiplomski studij Urbano šumarstvo, zaštita prirode i okoliša u prosjeku završe preddiplomski studij nakon 4,18 godina, drvnu tehnologiju nakon 4,28, a Šumarstvo nakon 4,64 godine. Pritom je njihova prosječna ocjena preddiplomskog studija na Šumarstvu 3,26, Drvnoj tehnologiji 3,34, a na Urbanom šumarstvu, zaštiti prirode i okoliša $3,44 \mathrm{~s}$ približno jednakom standardnom devijacijom (varijabilnosti) prosječne ocjene. 
Tablica 3. Tablica frekvencija anketiranih studenata prema prioritetu izbora Šumarskog fakulteta prilikom upisa

Table 3. Frequency table of surveyed students by studies and priority of Forestry faculty at the time of enrollment

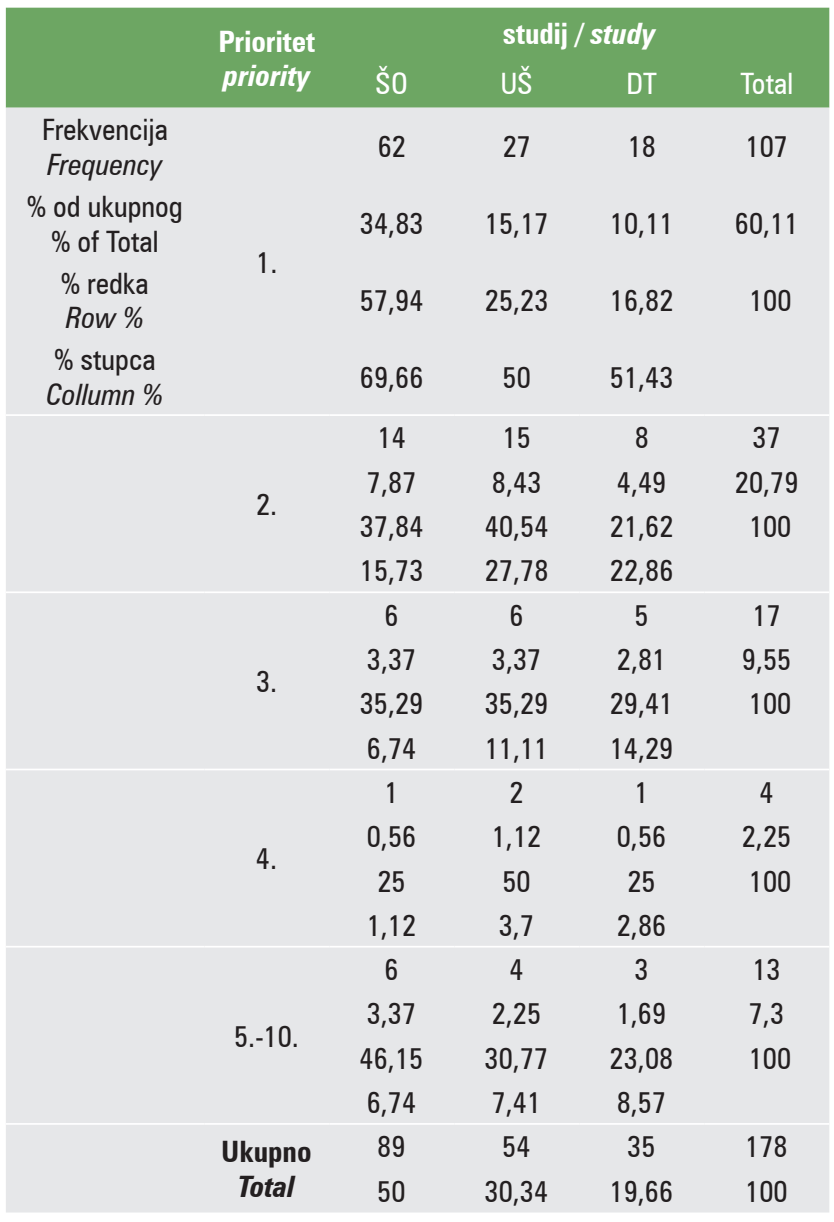

Nazivi preddiplomskih studija: Šo -Šumarstvo; UŠ -Urbano šumarstvo, zaštita prirode i okoliša; DT - Drvna tehnologija

Undergraduate study programmes: ŠO -Forestry; UŠ - Urban Forestry, Nature conservation and Environmental protection; DT - Wood Technology

Valja naglasiti da službeni podatci dostupni u ISVU sustavu daju niži prosjek ocjena nego je dobiven anketom, ali prati odnos studija dobiven kod anketiranih studenata, što je najvjerojatnije rezultat da neki od studenata (s nižim prosjekom) ne upisuju diplomski studij na Šumarskome fakultetu. Akademske godine 2015./2016. na preddiplomskom studiju Šumarstvo 107 studenata je završilo preddiplomski studij s prosječnom ocjenom $3,09 \pm 0,39$, na studiju Urbano šumarstvo, zaštita prirode i okoliša 81 student s prosječnom ocjenom 3,32 $\pm 0,39$, a na studiju Drvna tehnologija 47 studenata s prosječnom ocjenom $3,21 \pm 0,42$. Pregledom baze anketiranih studenata diplomskih studija samo njih 7 je imalo prekid u studiranju između završetka preddiplomskog studija i upisa diplomskog. Pet studentica je završilo preddiplomski 2014, jedan student 2011, a jedan 2012. godine. Negativni statističko značajni koeficijenti korelacije između trajanja preddiplomskog studija i prosječne ocjene ukazuju nam da studenti koji dulje studiraju imaju i nižu prosječnu ocjenu studija (Tablica 4 i Slika 2). Takva negativna veza duljine studiranja i uspjeha iskazanog ocjenom očekivana je, te je u skladu sa sličnim istraživanjima (Katsikas i Dergiades, 2009).

Uspješnost studiranja iskazana prosječnom ocjenom i trajanjem studija uspoređena je između muških i ženskih ispitanika te studijskih programa. Rezultati testiranja razlika statističke značajnosti razlika u trajanju i prosječnoj ocjeni prikazani su u Tablici 5.

Iz Tablice 5 i Slika 3 i 4 vidljivo je da ne postoji statistički značajna razlika u trajanju, kao ni u uspjehu preddiplomskog studija po studijima. Za razliku od nekih istraživanja (usp. Creech i Sweeder 2012), ne postoji statistički značajna razlika po spolu ni kod trajanja, ni kod prosječne ocjene preddiplomskog studija. Iako te razlike nisu statistički značajne (Tablica 5) na Slici 3 je vidljivo da su studentice na Urbanom šumarstvu, zaštiti prirode i okoliša u prosjeku kraće studirale od muških kolega, dok je na Drvnoj tehnologiji situacija obrnuta, a na Šumarstvu je ta razlika zanemariva. Što se tiče prosječnih ocjena studentice na Urbanom šumarstvu, zaštiti prirode i okoliša i Drvnoj tehnologiji imaju bolji prosjek od kolega, dok su na Šumarstvu kolege uspješniji. Interakcija spola i studija nam ukazuje da se trajanje i prosječna ocjena ponašaju približno jednako po spolu i smjeru studija, iako bi se prema $F$ vrijednosti interakcije za trajanje moglo zaključiti da bi veći uzorak možda i pokazao statistički značajnu razliku duljine trajanja preddiplomskog studija po studijima i spolu.

Jedan od glavnih ciljeva ovog istraživanja bio je spoznati koji su glavni faktori koji utječu na duljinu studija. U Tablici 6 prikazani su rezultati višestruke regresije, gdje je zavisna varijabla bila logaritmirano trajanje studija, a nezavisne varijable su bile spol, stipendija, prosječna ocjena preddiplomskog studija, završena srednja škola, prioritet Šumarskog fakulteta na listi pri upisu na fakultet, zaposlenost tijekom preddiplomskog studija te motivacija upisa na Šumarski fakultet.

Jedina varijabla koja se je za sva tri studija pokazala statistički značajnom je prosječna ocjena preddiplomskog studija. Pogledamo li procijenjene parametre koji su negativnog predznaka, nam potvrđuje da studenti koji studiraju kraće imaju i višu ocjenu studija. Prevedemo li te procijenjene parametre u mjesece, povećanje prosječne ocjene za 1 smanjuje trajanje studija na Šumarstvu za 8,93 mjeseca, 9,31 mjeseca na Urbanom šumarstvu, zaštiti prirode i okoliša i 9,98 mjeseci na Drvnoj tehnologiji. Što se tiče završene srednje škole za sva tri studija pokazalo se da gimnazijalci studiraju kraće, samo što na šumarskom odsjeku to nije statistički značajno, dok se na Drvnoj tehnologiji pokazalo da studenti sa završenom gimnazijom statistički značajno kraće studiraju od kolega sa završenom strukovnom školom. Primanje stipendije skraćuje vrijeme studiranja za sva tri studijska programa, s time 


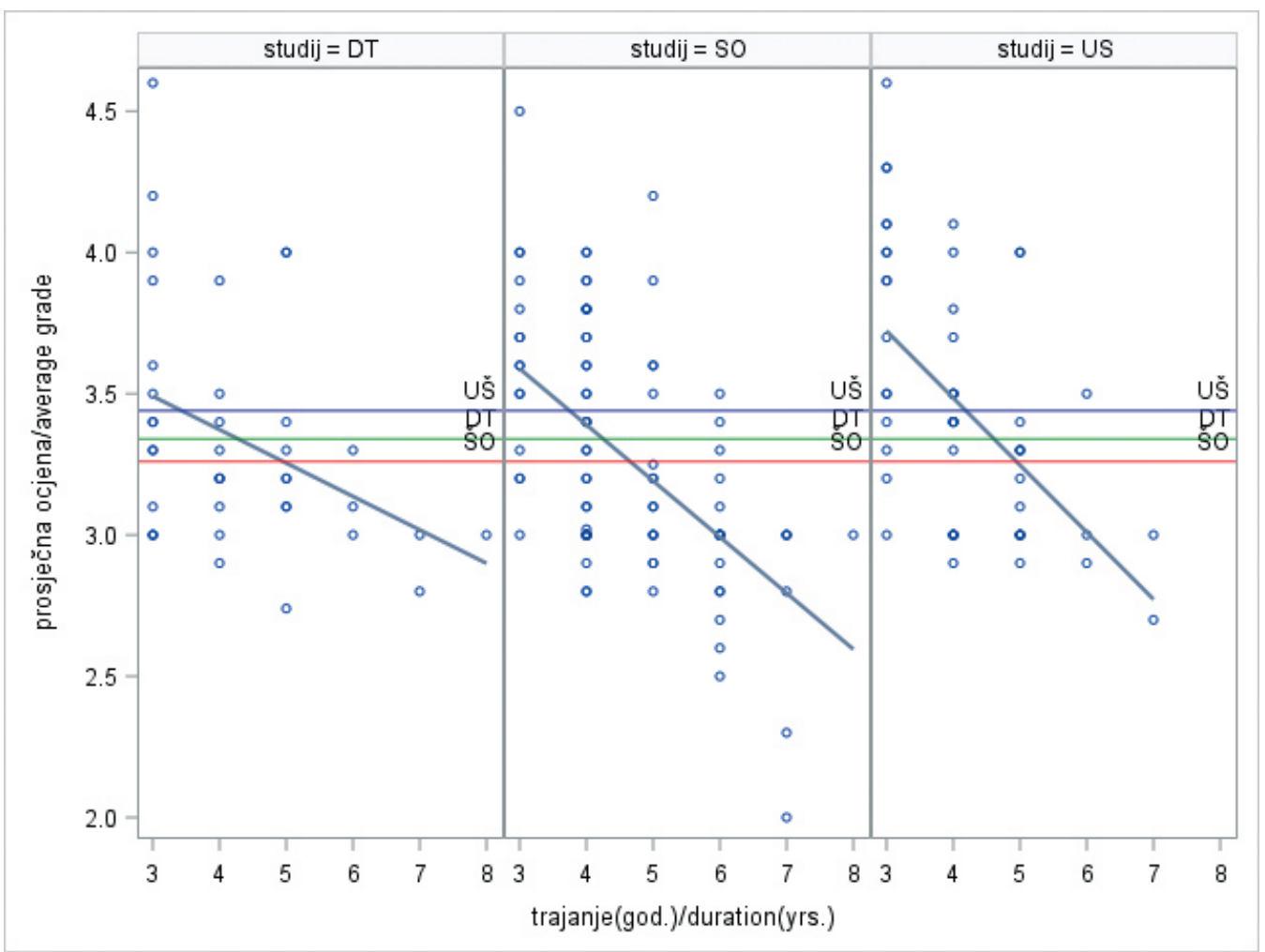

Slika 2. XY grafički prikaz (scatter plot) trajanja (god.) i prosječne ocjene preddiplomskog studija po studijima s ucrtanom prosječnom ocjenom cijelog studija. Plava padajuća linija prikazuje povezanost ocjene i trajanja studiranja.

Figure 2. Scatterplot of average grade vs. duration of undergraduate studies with horizontal lines representing total average grade. Blue descending line represents relationship of average grade and duration.

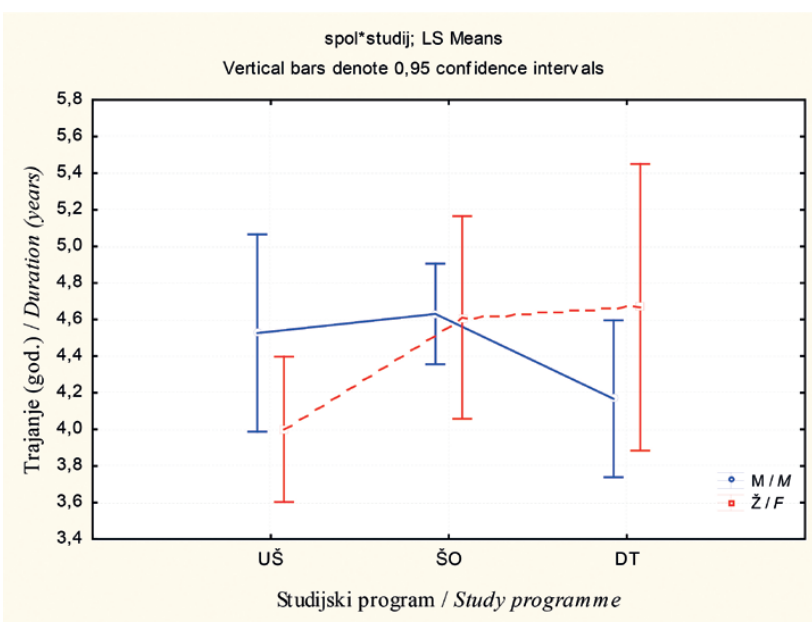

Slika 3. Aritmetičke sredine i $95 \%$ intervali pouzdanosti trajanja preddiplomskog studija po studijima i po spolu

Figure 3. Arithmetic means and $95 \%$ confidence intervals for duration of undergraduate studies by study programmes and sex

da kod Urbanog šumarstva, zaštiti prirode i okoliša taj utjecaj nije statistički značajan. Zaposlenost tijekom studija produljuje vrijeme studiranja za studente Šumarstva i Drvne tehnologije, odnosno negativno utječe na proces studiranja, što se pokazalo i u drugim istraživanjima (Callender, 2008), dok je kod Urbanog šumarstva, zaštiti prirode i okoliša obrnuto, ali se ta veza ni kod jednog studija nije pokazala stati-

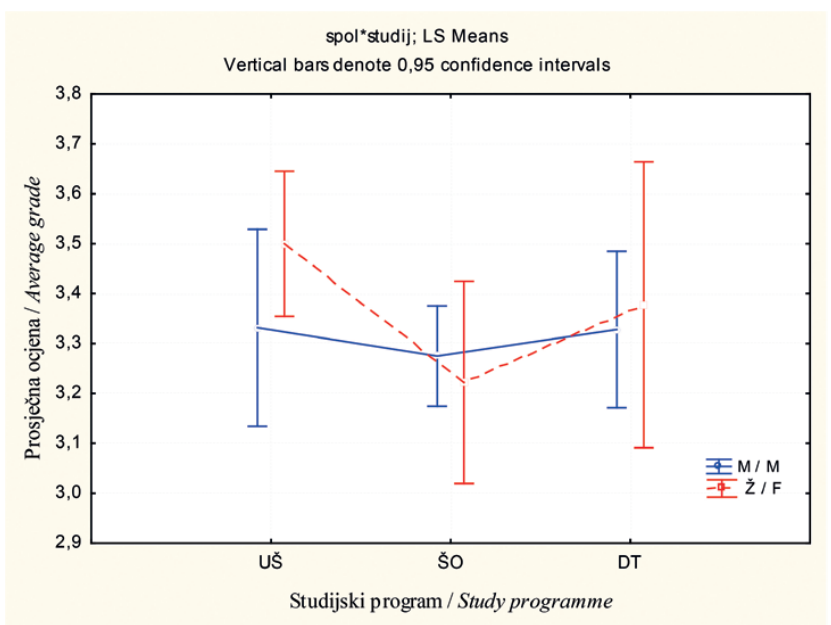

Slika 4. Aritmetičke sredine i $95 \%$ intervali pouzdanosti prosječne ocjene preddiplomskog studija po studijima i po spolu

Figure 4. Arithmetic means and 95\% confidence intervals for average grade of undergraduate studies by study programmes and sex

stički značajnom, slično kao i u istraživanju Katsikasa i Panagiotidisa (2010). Prioritet pri upisu također se nije pokazao statistički značajnim prediktorom duljine studiranja, dok se osobna motivacija pokazala bitnim prediktorom duljine studiranja, ali samo na studiju šumarstvo (ک̌O) se pokazala statistički značajnom. Utjecaj spola na trajanje studija statistički se značajnim prediktorom pokazao samo kod 
Tablica 4. Rezultati deskriptivne statistike: broj ispitanika, minimum, medijan, maksimum, aritmetička sredina i standardna devijacija kontinuiranih varijabli: dob, trajanje studija i prosječna ocjena preddiplomskog studija, te koeficijenti korelacije za trajanje i ocjenu

Table 4. Descriptive statistics (sample size, minimum, maximum, arithemtic mean and standard deviation) for continuous variables: age, study duration, average grade (GPA), and correlation coefficients between duration and average grade

\begin{tabular}{|c|c|c|c|c|c|c|c|c|}
\hline $\begin{array}{l}\text { Studif } \\
\text { study }\end{array}$ & $\mathrm{N}$ & $\begin{array}{l}\text { Varijabla } \\
\text { Variable }\end{array}$ & Min. & Median & Max. & $\begin{array}{l}\text { Aritmetička } \\
\text { sredina } \\
\text { Mean }\end{array}$ & Std Dev. & $\begin{array}{l}\text { Koeficijent } \\
\text { Korelacije } \\
\text { Correlation } \\
\text { coefficient }\end{array}$ \\
\hline \multirow{3}{*}{ Šo } & \multirow{3}{*}{$\begin{array}{c}92 \\
(49,7 \%)\end{array}$} & $\begin{array}{l}\text { Dob (god.) } \\
\text { Age (yrs) }\end{array}$ & 22 & 25 & 30 & 25,14 & 1,58 & \multirow{3}{*}{$\begin{array}{c}r=-0,56 \\
p<0,0001\end{array}$} \\
\hline & & $\begin{array}{l}\text { Trajanje (god.) } \\
\text { Duration (yrs) }\end{array}$ & 3,00 & 4,00 & 8,00 & 4,64 & 1,22 & \\
\hline & & $\begin{array}{l}\text { Prosječna ocjena } \\
\text { Average grade }\end{array}$ & 2,00 & 3,20 & 4,50 & 3,26 & 0,43 & \\
\hline \multirow{3}{*}{ UŠ } & \multirow{3}{*}{$\begin{array}{c}54 \\
(29,2 \%)\end{array}$} & $\begin{array}{l}\text { Dob (god.) } \\
\text { Age (yrs) }\end{array}$ & 22 & 24 & 28 & 24,56 & 1,36 & \multirow{3}{*}{$\begin{array}{c}r=-0,55 \\
p<0,0001\end{array}$} \\
\hline & & $\begin{array}{l}\text { Trajanje (god.) } \\
\text { Duration (yrs) }\end{array}$ & 3,00 & 4,00 & 7,00 & 4,18 & 1,05 & \\
\hline & & $\begin{array}{l}\text { Prosječna ocjena } \\
\text { Average grade }\end{array}$ & 2,70 & 3,40 & 4,60 & 3,44 & 0,45 & \\
\hline \multirow{3}{*}{ DT } & \multirow{3}{*}{$39(21,1 \%)$} & $\begin{array}{l}\text { Dob (god.) } \\
\text { Age (yrs) }\end{array}$ & 22 & 25 & 29 & 24,97 & 1,68 & \multirow{3}{*}{$\begin{array}{l}r=-0,38 \\
p=0,018\end{array}$} \\
\hline & & $\begin{array}{l}\text { Trajanje (god.) } \\
\text { Duration (yrs) }\end{array}$ & 3,00 & 4,00 & 8,00 & 4,28 & 1,32 & \\
\hline & & $\begin{array}{l}\text { Prosječna ocjena } \\
\text { Average grade }\end{array}$ & 2,74 & 3,20 & 4,60 & 3,34 & 0,41 & \\
\hline
\end{tabular}

ŠO - Šumarstvo; UŠ -Urbano šumarstvo, zaštita prirode i okoliša; DT - Drvna tehnologija

ŠO - Forestry; UŠ - Urban Forestry, Nature conservation and Environmental protection; DT - Wood Technology

Drvne tehnologije, gdje studentice dulje studiraju od muških kolega (Tablica 6).

Budući da su u anketi sudjelovali studenti svih pet diplomskih studija, dodatno je bilo moguće ocijeniti razlike u trajanju i prosječnoj ocjeni preddiplomskih studija, ovisno o tome koji su diplomski studij odabrali po završetku preddi-

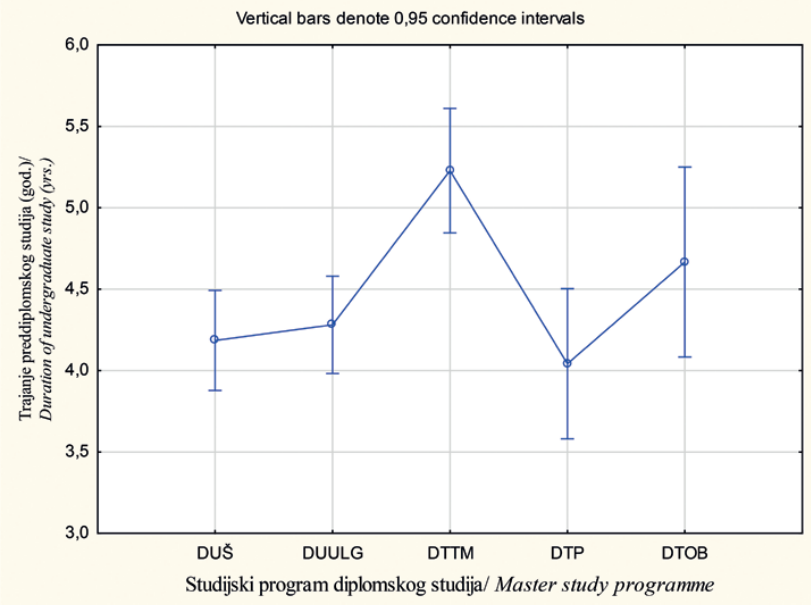

Slika 5. Aritmetičke sredine i 95\% intervali pouzdanosti trajanja preddiplomskog studija po smjerovima koje su studenti upisali na diplomskom studiju.

Figure 5. Arithmetic means and 95\% confidence intervals for duration of undergraduate study, shown by subsequently attended graduate study programmes plomskog. Rezultati analize varijance i regresije za navedene dvije varijable prikazani su u nastavku.

Rezultati analize varijance trajanja preddiplomskih studija prema upisanim diplomskim studijima kao i njihova prosječna ocjena prikazani su u Tablici 7. Vidljivo je da postoje statistički značajne razlike u trajanju preddiplomskog stu-

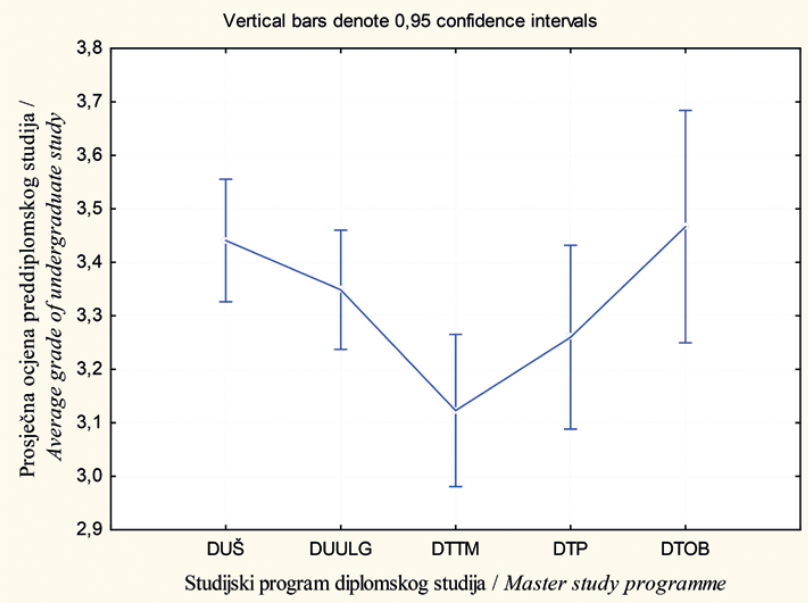

Slika 6. Aritmetičke sredine i $95 \%$ intervali pouzdanosti prosječne ocjene preddiplomskog studija po smjerovima koje su studenti upisali na diplomskom studiju

Figure 6. Arithmetic means and 95\% confidence intervals for average grade of undergraduate study, shown by subsequently attended graduate study programmes 
Tablica 5. Rezultati dvofaktorske analize varijance za varijable In trajanje i In prosječna ocjena preddiplomskog studija po studiju, spolu te interakciji studija i spola.

Table 5. Results of two-way ANOVA for In duration and In average grade by study, sex and interaction study*sex

\begin{tabular}{|c|c|c|c|c|c|c|c|}
\hline \multicolumn{2}{|l|}{$\begin{array}{l}\text { Varijabla } \\
\text { Variable }\end{array}$} & \multicolumn{3}{|c|}{$\begin{array}{l}\text { Ln trajanje } \\
\text { Ln duration }\end{array}$} & \multicolumn{3}{|c|}{$\begin{array}{l}\text { Ln prosječna ocjena } \\
\text { Ln average grade }\end{array}$} \\
\hline $\begin{array}{l}\text { Izvor varijabilnosti } \\
\text { Source }\end{array}$ & $\begin{array}{l}S S \\
D F\end{array}$ & $\begin{array}{l}\text { Varijanca } \\
\text { Variance }\end{array}$ & $\begin{array}{l}\text { F vrijednost } \\
\text { F Value }\end{array}$ & $\operatorname{Pr}>\mathrm{F}$ & $\begin{array}{l}\text { Varijanca } \\
\text { Variance }\end{array}$ & $\begin{array}{l}\text { F vrijednost } \\
\text { F Value }\end{array}$ & $\operatorname{Pr}>F$ \\
\hline $\begin{array}{l}\text { Studij } \\
\text { Study }\end{array}$ & 2 & 0,07129 & 1,06 & 0,3498 & 0,0300 & 1,84 & 0,1612 \\
\hline $\begin{array}{l}\text { Spol } \\
\text { sex }\end{array}$ & 1 & 0,0002 & 0,00 & 0,9500 & 0,0069 & 0,43 & 0,5135 \\
\hline $\begin{array}{l}\text { Studij }^{*} \text { spol } \\
\text { Study*sex }\end{array}$ & 2 & 0,1211 & 1,80 & 0,1691 & 0,0160 & 0,98 & 0,3762 \\
\hline
\end{tabular}

Tablica 6. Rezultati višestruke linearne regresijske analize za zavisnu varijablu In trajanje po studijima

Table 6. Results of multivariate linear regression for dependent variable In duration by study programmes

\begin{tabular}{|c|c|c|c|c|c|c|c|c|c|}
\hline $\begin{array}{l}\text { Varijabla } \\
\text { Variable }\end{array}$ & \multicolumn{9}{|c|}{$\begin{array}{l}\text { Studijski program } \\
\text { Study programme }\end{array}$} \\
\hline \multirow{3}{*}{$\begin{array}{l}\text { Ln(trajanje) } \\
\text { Ln(duration) }\end{array}$} & \multicolumn{3}{|c|}{ Šo } & \multicolumn{3}{|c|}{ UŠ } & \multicolumn{3}{|c|}{ DT } \\
\hline & \multicolumn{3}{|c|}{$\begin{array}{c}F(7 ; 79)=6,52 ; p<0,001 \\
\mathbf{R}^{2}=\mathbf{0 , 3 6 6}\end{array}$} & \multicolumn{3}{|c|}{$\begin{array}{c}F(7 ; 46)=4,71 ; p<0,001 \\
R^{2}=0,418\end{array}$} & \multicolumn{3}{|c|}{$\begin{array}{c}F(7,27)=7,81 ; p<0,001 \\
R^{2}=0,669\end{array}$} \\
\hline & $\mathrm{PE}$ & $\mathrm{t}$ & $p$ & PE & $\mathrm{t}$ & $p$ & PE & $\mathrm{t}$ & $p$ \\
\hline $\begin{array}{l}\text { Odsječak } \\
\text { Intercept }\end{array}$ & 2,61 & & & 2,51 & & & 2,25 & & \\
\hline $\begin{array}{l}\text { Spol (M/Ž) } \\
\operatorname{Sex}(M / F)\end{array}$ & $-0,03$ & $-0,53$ & 0,600 & $-0,07$ & $-1,18$ & 0,244 & 0,16 & 1,98 & 0,058 \\
\hline $\begin{array}{l}\text { Stipendija (ne/da) } \\
\text { Grant (No/Yes) }\end{array}$ & $-0,11$ & $-1,98$ & 0,051 & $-0,10$ & $-1,46$ & 0,152 & $-0,26$ & $-3,63$ & 0,001 \\
\hline $\begin{array}{l}\text { Prosječna ocjena } \\
\text { Average grade }\end{array}$ & $-0,29$ & $-5,21$ & $<0,001$ & $-0,25$ & $-3,54$ & $<0,001$ & $-0,18$ & $-2,31$ & 0,028 \\
\hline $\begin{array}{l}\text { Srednja škola (struk/gimn) } \\
\text { High school type } \\
\text { (voc./gymn.) }\end{array}$ & $-0,01$ & $-0,07$ & 0,943 & $-0,05$ & $-0,64$ & 0,527 & $-0,31$ & $-4,24$ & $<0,001$ \\
\hline $\begin{array}{l}\text { Prioritet (1 maks) } \\
\text { Priority (1 max) }\end{array}$ & $<0,001$ & 0,02 & 0,980 & 0,009 & 0,41 & 0,683 & 0,01 & 0,76 & 0,454 \\
\hline $\begin{array}{l}\text { Zaposlenost (ne/da) } \\
\text { Employment (no/yes) }\end{array}$ & 0,07 & 1,60 & 0,11 & $-0,03$ & $-0,46$ & 0,648 & 0,11 & 1,47 & 0,152 \\
\hline $\begin{array}{l}\text { Motivacija (obtelj/osobna) } \\
\text { Motivation (family/personal) }\end{array}$ & $-0,17$ & $-1,98$ & 0,051 & $-0,15$ & $-1,57$ & 0,123 & $-0,22$ & $-1,48$ & 0,151 \\
\hline
\end{tabular}

PE - procijenjeni parametar, Šo -Šumarstvo; UŠ -Urbano šumarstvo, zaštita prirode i okoliša; DT - Drvna tehnologija $P E$ - parameter estimate, ŠO -Forestry; UŠ - Urban Forestry, Nature conservation and Environmental protection; DT - Wood Technology

Tablica 7. Rezultati jednofaktorske analize varijance za In trajanje i In prosječne ocjene preddiplomskog studija po smjerovima koje su studenti upisali na diplomskim studijima. Aritmetičke sredine i standardne devijacije su za izvorne podatke.

Table 7. Results of one-way ANOVA for variables In duration and In average grade on undergraduate studies, between graduate studies groups of students. Means and standard deviations are for original data

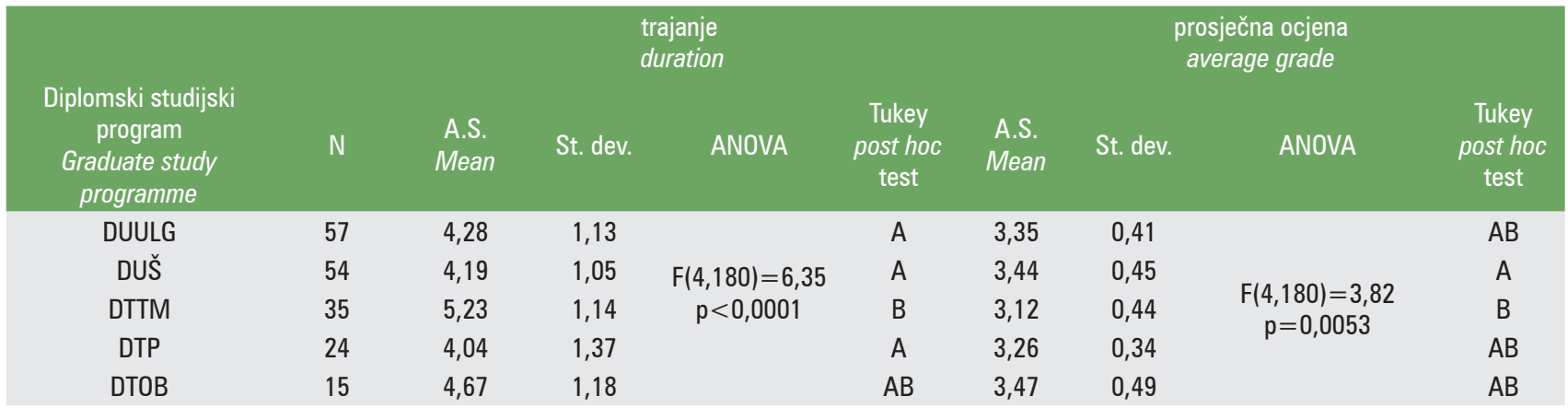

A.S. - aritmetička sredina; St.dev. - standardna devijacija; Tukey-ev post hoc test: različita slova znače statistički značajnu razliku $(p=0,05)$

A.S. - arithmetic mean; St.dev. - standard deviation; Tukey post-hoc test: different letters mark statistical significant difference $(p=0,05)$ 
dija, kao i prosječnoj ocjeni preddiplomskog studija prema kasnije upisanim diplomskim studijima. U prosjeku su na preddiplomskom studiju najkraće studirali studenti diplomskog studija Drvnotehnološki procesi (DTP) $(4,04$ god) iako je njihova standardna devijacija (varijabilnost) najveća (1,37 god.), a najdulje studenti diplomskog studija smjer Tehnike, tehnologija i management (DTTM) $(5,23$ god.). Tukeyev post-hoc test pokazuje da se u trajanju preddiplomskog studija statistički značajno razlikuju studenti koji su upisali diplomski studij smjer Tehnike, tehnologija i management, od studenata koji su upisali smjer Uzgajanje i uređivanje šuma s lovnim gospodarenjem (DUULG) (4,28 god.), studij Urbano šumarstvo (DUŠ) $(4,19$ god.) i DTP $(4,04$ god.), a ne razlikuju se u trajanju od studenata koji su upisali Oblikovanje proizvoda od drva (DTOB) (4,67 god.). Najbolju prosječnu ocjenu preddiplomskog studiju imali su studenti koji su upisali diplomski studij DTOB $(3,47)$, dok su najlošiju prosječnu ocjenu imali studenti koji su upisali diplomski studij smjer tehnike, tehnologija i management $(3,12)$.

Tukeyev post hoc test potvrđuje da su prema prosječnoj ocjeni preddiplomskog studija jedino studenti koji su upisali diplomski studij Urbano šumarstvo, zaštita prirode i okoliša $(3,44)$ imali statistički značajno viši prosjek ocjena preddiplomskog studija od studenata diplomskog studija Tehnike, tehnologija i management $(3,12)$. Ostali studiji se ne razlikuju statistički značajno. Iako studenti diplomskog studija Oblikovanje proizvoda od drva imaju najvišu prosječnu ocjenu preddiplomskog studija njegov $95 \%$ interval pouzdanosti je "najširi", jer ima najmanje studenata (15), pa je standardna pogreška najveća.

\section{ZAKLJUČCI CONCLUSIONS}

Rezultati dobiveni analizom ankete studenata Šumarskog fakulteta pokazali su da je trajanje studija povezano s uspjehom iskazanim pomoću prosječne ocjene, što ukazuje da ne treba zanemariti niti jedan od ta dva pokazatelja pri ocjeni konačnog uspjeha studenata. Osim toga potvrđeno je da stipendiranje, kao i osobna motivacija skraćuju vrijeme studiranja. Utvrđene razlike u ocjenama i trajanju studija između pojedinih preddiplomskih, kao i diplomskih studija, mogle bi poslužiti kao polazišta za buduće promjene i unaprjeđenje studijskih programa.

Uz sva ograničenja anketnog ispitivanja, dobiveni rezultati pokazuju da se anketa i provedene statističke analize mogu biti vrlo korisna sredstva za prikupljanje podataka o studiranju te za analizu uspješnosti studija.

Nastavak istraživanja pomoću sličnih anketa bilo bi poželjno provesti, kako bi se mogao pratiti trend uspješnosti studiranja tijekom vremena, posebice u okolnostima kada zbog demografskih i društvenih promjena nastaju novi izazovi pred visokoškolskim šumarskom naobrazbom u Republici Hrvatskoj.

\section{ZAHVALA \\ ACKNOWLEDGEMENT}

Istraživanje i analiza podataka provedeni su uz potporu Sveučilišta u Zagrebu „Analiza trajanja studiranja na preddiplomskim studijima Šumarskog fakulteta Sveučilišta u Zagrebu“.Zahvaljujemo studentima na suradnji i Mirjani Prša na pomoći oko podataka o prosječnim ocjenama iz ISVU-a.

\section{LITERATURA}

\section{REFERENCES}

- Anić, I., 2019: Važnost šumarske nastave i znanosti na Sveučilištu u Zagrebu za razvoj hrvatskog šumarstva. Šumarski list 143(12): 59-69.

- Borčić, M. (ur.), 2003: Informacijski sustav visokih učilišta. Ministarstvo znanosti i tehnologije Republike Hrvatske, Zagreb, 63 str.

- Božić, M. (gl. ur.), 2018: 120 godina Šumarskog fakulteta Sveučilišta u Zagrebu. Šumarski fakultet Sveučilišta u Zagrebu, Zagreb, 264 str.

- Callender, C., 2008: The impact of term-time employment on higher education students academic attainment and achievement. Journal of Education Policy, 23(4): 359-377.

- Creech, L. R., Sweeder, R. D., 2012: Analysis of student performance in large-enrollment life science courses. CBE life sciences education, 11(4): 386-91.

- Katsikas, E., Dergiades, T., 2009: Using degree grades as indicator of performance in a Greek university of social studies. Evaluation \& Research in Education, 22(1): 33-49.

- Katsikas, E., Panagiotidis, T., 2010: Student status and academic performance: an approach of the quality determinants of university studies in Greece. GreeSE paper No. 40. Hellenic Observatory, London School of Economics and Political Science, London, UK, 45 str.

- SAS Software 9.4. SAS Institute Inc., Cary, NC

- Tešija, R. A., Maslov Kružičević, S., Banožić, A., Esteban, C. D., Sapunar, D., Puljak, L., 2013: Impact of extended course duration and stricter study organization on attrition and academic performance of medical students. Croatian medical journal, 54: 192-197.

- TIBCO Software Inc., 2018: Statistica (data analysis software system), version 13. http://tibco.com.

- Zajednička deklaracija europskih ministara obrazovanja potpisana u Bologni, Bolonjski proces, Europski prostor visokog obrazovanja, 19.6.1999. https://mzo.hr/sites/default/files/migrated/bolonjska-deklaracija.pdf

- Zrakić, M., Juračak, J., 2012: Analiza uspjeha studenata agroekonomskih studija na Agronomskom fakultetu u Zagrebu. Agroeconomia Croatica 2 (1): 1-7. 


\section{SUMMARY}

Although forestry is often considered as a traditional field of applied science, it resumes its importance in context of increased awareness of climate change and benefits coming from natural ecosystems. Updated and contemporary study programmes are needed to ensure an adequate education on managing forest ecosystems and its products.

A better insight in student background and their motivation for studies are welcome to improve the study programmes and also to find the ways how to help students achieve better results. A case study research was carried out to measure success of studies by duration of studies and average grades achieved, with possible causes. Three undergraduate study programmes on Zagreb Faculty of Forestry were analyzed (Forestry $\mathrm{N}=94$, Urban forestry $\mathrm{N}=54$ and Wood Technology $\mathrm{N}=39$ ), with data acquired from a questionnaire among forestry graduate students on the same faculty academic year 2016/2017. A Factorial ANOVA was performed to test differences between the studies, and a multivariate linear regression for the influence of predictor variables on the duration of study.

Although this profession is associated with people from rural areas, about one third of all students comes from the capital city (Figure 1). Students of Wood Technology (DT) are mostly coming from vocational schools (70\%) while Forestry (ŠO) and Urban Forestry (UŠ) students are mostly from gymnasiums (67\% and $83 \%$ ). For about $91 \%$ of students main motivation was a personal sake rather than a family interest (9\%). Average scores and the duration of study on three study programmes have not been proven significantly different between the studies, nor between male and female students (Table $5)$. A longer time of study is proven to negatively correlated with the average grades on all study programmes: ŠO $(r=-0,56)$, UŠ $(r=-0,55)$ and DT $(r=-0,38)$ (Table 4.). Statistically significant predictor for duration (with logarithmic transformation) on all study programmes in regression analysis was the average grade, with negative sign, thus leading to a shorter study time. Additional statistically significant predictors for ŠO were obtained grant and personal motivation (negative sign), and for DT were sex, obtained grant, and type of high school (Table 6).

KEY WORDS: academic performance, average grade, duration of study, regression analysis, study programme 